\title{
Research and Practice of Applied Talent Cultivation Model for Electrical Engineering and Automation
}

\author{
Chang Su ${ }^{a}$, Chao Yang ${ }^{b}$, Chong Tian ${ }^{c}$ \\ Heilongjiang University of Technology, Heilongjiang, Jixi, 158100 \\ aemail: jxdxsc@163.com,email: jxdxyc@163.com, cemail: tianchong@163.com
}

Keywords: electrical engineering and automation; applied talents; training mode;

\begin{abstract}
Looking at the model of personnel training in various colleges and universities in the country, the first is the model of discipline-based personnel training; the second is the cultivation model of science and technology talents; the third is the training model of technical and skilled personnel. The three current personnel training models have different points in their educational focus and teaching. The first model focuses on cultivating scholar-type research talents; the second model trains engineer-type talents with both theoretical foundations and strong hands-on skills; the third model cultivates talented technicians who have sufficient theoretical knowledge and strong practical skills. The objectives and levels of the three modes of training are not the same, so the requirements for teaching content and teaching methods are not the same. All colleges and universities must also choose a training mode or a model based on their own school's positioning and educational objectives. For the training of electrical engineering and automation professionals, it should be positioned to cultivate "application-oriented undergraduates." Therefore, this paper has studied and explored the application-oriented personnel training model for electrical engineering and automation.
\end{abstract}

\section{Introduction}

With the advent of the 21st century, the demand for talent has changed from a knowledge-based, skill-based model to an application-based model. This requires that the cultivation of talents in universities should combine the three aspects of knowledge, ability and quality in order to meet the needs of society for talents. At present, the training of talents in institutions of higher learning in our country mainly uses schools as the main body to impart various professional knowledge, and it is not enough to interact with various units outside the school, especially potential employers in the future. Although there are practical teaching steps in the teaching plan and a certain amount of time-achieving scores for off-campus practice or internships, as the rapid development of society, especially the demand for applied talents, the cultivation of applied undergraduate talents is adaptable. The current need for the development of higher education in our country is also an inevitable requirement for the transition process of Chinese universities from elite education to popular education. The exploration and establishment of the application-oriented undergraduate talent training system for higher education institutions in China is to better reflect the principles of classified guidance and better meet the various needs of today's society for the cultivation of applied talents. At present, China has entered the stage of popularization of higher education. The demand for schools in the popularization of higher education is that students can meet the needs of enterprises more closely and meet the needs of the society. In the process of training, they must also pay attention to the training of students' practical ability and hands-on ability.

2. The current colleges and universities in the cultivation of applied undergraduate talent problems

\subsection{Focus on the cultivation of students' theoretical knowledge}

The proportion held by the theoretical class was too high, and to a certain extent, students' 
practical ability training was neglected. There were few practical courses and experimental courses offered by schools, and some key courses did not even offer corresponding experimental courses; at the same time, in the process of imparting theoretical knowledge, colleges and universities do not have a certain degree of selectivity and pertinence. The teaching of theoretical knowledge can't keep up with the pace of development of the enterprise, resulting in the disconnection of professional theoretical teaching and practicality. The theoretical teaching of the classroom is out of step with the actual needs of the enterprise. For example, the teaching of power systems and automation in universities is still based on the principle of basic protection of relay protection, and the laboratory is still at the level of the 1990s, that is to say, traditional electromagnetic protection devices were used. The microcomputer relay protection device and integrated automation system at the current equipment operation site are seriously out of touch. After the students get employed, they are facing new microcomputer protection devices and integrated automation systems.

\subsection{The speed of development of college education can't keep up with the changes in social needs}

As the traditional university teaching model and teaching materials (especially applied knowledge and textbooks) lag behind the development of science and technology. The demand rate of the talent market has been changing with the development of science and technology. Therefore, this difference in speed has caused a large gap between the actual needs of professionals and the market. Such a gap directly results in two consequences. On the one hand, many theoretical research talents who are subject to general education cannot find work; on the other hand, companies cannot find high-quality applied talents. For the theoretical research students who are able to work, they generally still need one year or more of time to adjust and follow up their studies before they can slowly adapt to the demands of the society.

\subsection{Allowing companies to participate in the training of talents in schools}

For most schools, the road of training applied talents tends to go its own way and rarely involve companies. Therefore, students who have been educated by the school need to re-learn and re-face new contents according to their choice of jobs. Most students feel that the knowledge they have learned in school cannot be used at all or they do not know how to use the professional knowledge they have learned. They simply do not know what kind of work they can do in the future when they go to work, and they lack some confidence in their employment.

\section{To improve the comprehensive quality of students for the research of applied talent cultivation}

Colleges and universities are places where talents are trained. Not only are they required to impart professional and technical knowledge, but also to cultivate students with a high overall quality, so that students become talented people with excellent academic achievements. In order to improve the overall quality of students, we started by cultivating students to learn how to learn, learn how to live, and learn how to behave.

\subsection{Strengthen students' cultivation habits}

Strengthen student development education, professional teacher part-time class teacher to change the traditional nanny-style management, become a tutor-type guidance. Guide students in thinking, guide students in their studies, care for students in their lives, and teach and educate people. Good quality has formed a good learning atmosphere and promoted students to lay a solid foundation for professional knowledge. The scores of participating students have also been greatly improved, reaching graduate student admission scores, breaking the records of graduate students in electrical engineering and automation majors, changing the people's understanding of low-quality teaching in electrical engineering and automation, and inspiring students Love of professional enthusiasm, removed the low self-esteem mentality. This year there are many people admitted to graduate students, advanced to a major university. The electrical engineering and automation majors have 
embarked on a path of sound development.

\subsection{Strengthening students' comprehensive quality training}

We expanded quality education in classroom teaching and various activities, organized and carried out a series of rich and varied, healthy and beneficial science and technology, culture and sports activities, inspiring students' spirit of unity and mutual assistance. Organize and guide students to design and implement activities and competitions on their own. The intensive activities have enabled students to recognize their organizational capabilities, their team spirit has been promoted, their self-confidence has doubled, their professional cohesion has been greatly enhanced, and their overall development has been promoted. The overall quality of students has also been significantly improved.

\subsection{Strengthen the cultivation of students' application ability and innovation ability}

Combined with research topics to guide and guide students to participate in discipline competitions, electronic innovation contest, college students start-up projects. Encourage and mentor students to apply for professional skills certificates, inspire students to master professional and technical interests, improve application skills, and master professional skills. Encourage students to choose the graduation design topic according to their orientation of employment. The tutor will check and approve and strengthen supervision and inspection to improve students' application ability and innovation ability. Improve the quality and level of application-oriented personnel training.

\section{The characteristics of practice teaching and the construction of teaching mode}

The electrical engineering and automation major has built a practical teaching content system that combines the in-class system, practical skills training, and extracurricular open experimentation; and the combination of professional quality development training in the school and off-campus practice training. It includes teaching practice, professional practice and science and technology practice. During the specific implementation process, through several revisions of the talent cultivation program, the curriculum design and engineering training weeks have been increased, so that the electrical engineering profession has been practiced for not less than 40 weeks. Gradually increase the courses for independent courses in experimental links, from physics experiments to electrical measurements, and basic experiments in electronic technology and now to professional comprehensive experiments. The total number of experimental courses that have comprehensive and design experiments exceeds $90 \%$.

The electrical engineering and automation major focuses on the requirements of the application-oriented engineering and technical personnel and categorizes the practical teaching system into the following three levels.

1) Fundamental skill level: Including public basic experiment, subject-based experiment, internship and project internship, and basic skills training;

2) Comprehensive application ability and preliminary design ability layer: Including professional experiment, professional internship, curriculum design, and training for comprehensive application and design ability;

3) Engineering practice and innovation ability Training layer: Including graduation design, engineering project training and scientific and technological innovation, product research and development, and engineering practice ability and innovation ability training.

This kind of three-level practical teaching system has evolved from single to comprehensive and has enabled the training of engineering application capabilities to increase.

\section{Training of applied talents in electrical engineering and automation}

\subsection{Optimized course system}

Constructing a scientific curriculum system is the basis for cultivating qualified application 
talents. How to combine strong and weak electricity, hardware and software, electrical control and information technology is the key to the optimization of the curriculum system. In the course of optimizing the curriculum system, we put forward the principle of "laying a solid foundation, emphasizing the backbone, and valuing practice" and innovating the teaching plan. In the curriculum setting, highlight the core knowledge and ability of the professional, gradually implement the modular and project-based curriculum setting, and integrate the corresponding courses with the parallel or in-line method of in-class teaching and extra-curricular practice. In the course arrangement, on the one hand, it establishes knowledge points for each module's technical capabilities, establishes teaching priorities, and establishes teaching sequences; on the other hand, it conforms to the development trend of automation and intelligence in the profession, and strengthens and highlights computer technology and related curriculum teaching. The curriculum system is optimized to build a professional curriculum system with a stable knowledge structure and clear knowledge, so that students can learn what is important in the actual work and they must have a firm grasp of knowledge and ability.

\subsection{Strengthen practice teaching}

With broad and solid theoretical knowledge, how to translate these knowledge into practical applications is the key to training applied talents. To achieve this goal, we have taken enhanced measures. First of all, to improve teaching conditions in the teaching process, encourage and require teachers to use case teaching methods and on-site teaching methods as far as possible; to use modern teaching tools and facilities as much as possible so that students can grasp the methods and processes of theoretical guiding practice more intuitively and vividly. Secondly, on the basis of a certain theoretical basis, the university will continue to practice for four years, from curriculum experiments, curriculum design, production internships to graduation design, to form a systematic, point-to-face, basis-to-integration, hierarchy, and schedule, a full range of practical teaching systems. Design, develop products and debug systems by themselves, with the emphasis on cultivating their hands-on ability, the ability to consult data and the ability to translate theory into practice. Thirdly, in the practical courses, the training of applied talents focuses on participation. Participating in the actual operation of the company's site, understanding the entire process and overview of production; Participating in the design of the project, so that students are prepared to participate in the selection of topics, design, Experiments and seminars have strengthened their application capabilities and cultivated their innovative spirit. In particular, graduation design should try to select cooperation research projects with enterprise units, and invite business units to participate in graduation design guidance. This not only solves the actual problems of the unit, but also has direct guiding significance for the students' future work.

\subsection{Guide and encourage technological innovation}

If it is confined to a theoretical basis and can actually operate, it is only the technicians who graduated from technical secondary school or college. The electrical engineering and automation major is the cradle of undergraduate applied and compound scientific and technical personnel training, and it is also necessary to pay attention to the cultivation of students' scientific and technological innovation ability. When students have mastered some theoretical knowledge and practical ability, such as after the junior year, there must be plans to guide and encourage students to participate in a number of professional and technical training courses, technology research and development interest groups, as well as a series of activities of electronic associations to enhance their professional perceptual knowledge in technology, in turn, to participate in extracurricular or off-campus amateur technology research projects, participate in school-level, provincial-level and even national-level electronic design science and technology works exhibitions and competitions, the process of participation is the process of improvement.

\subsection{Reform assessment system}

The research of the applied talent training model is a systematic project. For the students we cultivate, whether he is an individual talent or not, is it right? We should expect that the applied 
talents must have a scientific and perfect assessment system for testing. The usual teaching and education quality inspections mainly include: classroom performance, mid-term, final exams, and experimental assessments. For applicative talents, their assessment content is lacking, and they cannot fully reflect the application ability of engineering science and technology talents. It is necessary to carry out reforms and establish a scientific and rational appraisal system of applied talents. Therefore, in addition to the regular teaching assessment, we must increase: (1) the evaluation of practical ability. Autonomous experimental results, design-type experimental results, and course design results; (2) innovation ability evaluation. Comprehensive evaluation of the design or graduation design, participation in extracurricular science and technology works, results of the competition, and participation in the science and technology projects must be evaluated accordingly. Comprehensive assessment of teaching, practical ability, and innovative ability, to get a fair and objective evaluation of each student's learning situation, a more practical application of talent assessment and evaluation system. In this way, we can test whether our teaching effect achieves and completes the teaching goal.

\section{The effect of the applied talent model training in electric and automation specialty}

Implementation of a new application-oriented talent training program, and the training mode for electrical engineering and automation professionals has been effectively implemented.

\subsection{One system}

Establish the teaching philosophy of integration of theoretical teaching and practical teaching. During the process of training and training for students from school to graduation, the main thread of theoretical quality and technical application has always been adopted. Theoretical teaching and practical teaching are only the differences between educational content and educational methods. They are two aspects of the talent cultivation process and they are unified. Therefore, all the professional teachers have undertaken corresponding teaching tasks in the theoretical class and practical teaching modules, so that the students have received comprehensive and multi-level theoretical quality training and practical training.

\subsection{Two parallel}

On the one hand, there is a parallel between theoretical teaching and practical teaching. The new talent cultivation model walks in phases and levels in both theory and practice. The four theoretical teaching groups and the four practical teaching modules correspond to each other and are independent. Students can learn theoretical knowledge while study and practice in laboratories and off-campus practice bases, verify and apply the theoretical knowledge learned in the engineering environment, gradually form project awareness, and cultivate technical application capabilities. On the other hand, it is the parallel of school cultivation and enterprise training. Many years of good school-enterprise relations established by specialized colleges and universities, and a large number of networked resources provided by graduating students who have made meritorious deeds in their jobs, these have provided us with a stable platform for school-industry joint practice teaching. Throughout the practical teaching process, students have four opportunities to study outside the school's practical teaching base. The content of the study will increase from single to specific and then become comprehensive. The purpose of learning will be changed from understanding and understanding to application innovation. This kind of uninterrupted school and the co-cultivation of enterprises have accelerated the pace of adapting students to practical needs such as electricity production, construction, and management, shortening the maturation time of applied talents in electrical engineering, and providing enterprises with opportunities to discover and hire talents.

\subsection{Three combinations}

Based on professional characteristics and talent training goals, and combined with their own advantages, we have repeatedly analyzed and thought about the content of practical teaching, and put forward the idea of optimal integration of "three combinations", that is, combination of 
experiment and practice, combination of practice and design (the combination of curriculum design and graduation design), combination of design and engineering practice. Experiments and internships are two links in the practical teaching process. In order to achieve the combination of experiment and practice, we have adopted content integration and site integration. In terms of content, on the one hand, through the establishment of a new system of practical teaching, the role of each link is clearly defined to avoid duplication of content; on the other hand, the proportion of experiments and internships is gradually adjusted, and experimental projects are gradually formed into comprehensive design internship projects. Curriculum design and graduation design focus on specific issues in engineering practice. In terms of operation, the project management system for project reporting and project review is established. Projects that do have creative and engineering practices are supported and focused, and engineering practice is carried out at the practice base. This school-enterprise interaction, "study, production, research" combined, so that "engineering application-oriented personnel" training has been implemented.

\subsection{Four levels}

To cultivate talents for engineering application, it is necessary to emphasize basic and strong quality, but also to apply innovation and innovation in the form of "learning for results". To achieve this goal, we proceed from theoretical knowledge to practical training in four levels. The first level series is based on the basic theory of engineering and the basic concept of engineering as the core of the curriculum and the engineering quality of the medium. The second series of series is the training of the professional basic theory of electrical engineering and the training of basic practical skills to build a professional learning platform; The three-level series is the study of the technical structural theory of electrical engineering and the training of engineering application ability, and the training of engineering technical quality. The fourth-level series is the comprehensive study and training of the contents of the electrical engineering professional field to realize engineering application and innovation.

\section{Summary}

"It takes ten years to grow a tree and a hundred years to bring up a generation of good men", talent cultivation is a big project. Through the research and exploration of the applied talent cultivation model for electrical engineering and automation, optimizing curriculum settings, intensifying practical teaching, guiding and encouraging technological innovation, and reforming the assessment system, a design, experiment, and discussion have been conducted. It can be said that it basically constitutes a training model for applied talents in electrical engineering and automation. However, there are still some problems that need improvement. (1) The number of academic hours for professional theoretical courses in the teaching plan needs to be further reduced. The actual courses and experimental courses need to be further increased. According to the information returned by the employer, the existing professional theoretical courses need to be adjusted. Some teacher ideas need to be further updated. (2) How to allow more students to participate in the project and enter the role, and more coordination work is needed. On the one hand, the students specializing in the textbooks occupy part of the time for doing the research. On the other hand, the students have to undertake some specific practical tasks. The engineers have a large amount of pre-work training for the students. (3) Colleges and universities cooperate with scientific research institutes to educate and train technical and applied talents. They can realize the complementary advantages of educational resources. Only by further updating ideas and strengthening management can we achieve good educational results.

\section{Acknowledgement}

This project is the key project of higher education teaching reform research of education department of Heilongjiang province in 2017.Project name: Research and practice on training mode of characteristic technical talents in coal-power-chemical electrical engineering and automation. 
Project number: SJGZ20170038

\section{References}

[1] Xue-Jun L I, Jie L I, Ming-Jing L I. Discussion on the Reform of the Practice Teaching in the Major of Electrical Engineering and Automation[J]. Journal of Changchun University, 2013.

[2] Cai L, Wang X Y, Qiu G, et al. Some Thoughts about Practice Teaching of Electrical Engineering and Automation Major [J]. Computer Knowledge \& Technology, 2016.

[3] Zhang Y F, Liu J W, Hao S P, et al. Practice and Thinking of Building a Practical Teaching System of Electrical Engineering and Automation Specialty-Taking Nanjing Institute of Technology for Example[J]. Journal of Nanjing Institute of Technology, 2012.

[4] Chen L. Research on the Applied Talent Cultivation for the Major Electrical Engineering and Automation in Independent Colleges [J]. Journal of Anhui University of Technology, 2016.

[5] Chen P. Discussion on the Curriculum Reform of Electrical Automation Major in Newly Built Universities[C]// International Conference on Machinery, Electronics and Control Simulation. 2017.

[6] Sun W J, University Y N. Exploration of Simulation Technology in Teaching Reform for Electrical Engineering and Automation Specialty [J]. Research \& Exploration in Laboratory, 2016.

[7] Sun C. Research on electrical engineering and automation [J]. World Nonferrous Metals, 2016.

[8] Bai Y, Yang T, Kou B. Reducing detent force and three-phase magnetic paths unbalance of PM linear synchronous motor using modular primary iron-core structure[C]// International Conference on Electrical Machines and Systems. IEEE, 2015:1743-1748.

[9] Benaicha A, Mourot G, Benothman K, et al. Determination of principal component analysis models for sensor fault detection and isolation [J]. International Journal of Control Automation \& Systems, 2013, 11(2):296-305.

[10] Faruque M A A, Vatanparvar K. Modeling, analysis, and optimization of Electric Vehicle HVAC systems[C]// Asia and South Pacific Design Automation Conference. IEEE, 2016:423-428.

[11] Balakrishna P, Rajagopal K, Swarup K S. Application benefits of Distribution Automation and AMI systems convergence methodology for distribution power restoration analysis [J]. Sustainable Energy Grids \& Networks, 2015, 2:15-22.

[12] Raza A, Xu D, Su X, et al. Invasion of high voltage direct current till 2014[C]// IEEE International Conference on Control Science and Systems Engineering. IEEE, 2015:151-157.

[13] Lin W, Zheng Q L, Xu Y Z, et al. Temperature effect on performance and reliability of QR tapped-inductor Buck LED driver[C]// Power Electronics and Application Conference and Exposition. IEEE, 2015:1397-1400.

[14] Liu X, Kan F, Feng Q, et al. Teaching Reform of Electrical Engineering and its Automation under the Background of Outstanding Engineers[C]// International Conference on Education, Management, Computer and Society. Atlantis Press, 2016. 